\title{
Physical and biochemical properties of selected tropical fruits
}

\author{
K.A. Athmaselvi*, Pandian Jenney, C. Pavithra, and Ishita Roy \\ Department of Food Process Engineering, SRM University, Kattankulathur - 603203, Tamil Nadu, India
}

Received May 17, 2013; accepted December 31, 2013

\begin{abstract}
A b s tract. This study was conducted to determine the physical and biochemical properties of guava, sapota, and papaya. The physical properties studied were: dimensions, shell ratio, surface area, bulk and true density, porosity, sphericity, packing coefficient, aspect ratio, and roundness index. The specific heat at various mass fractions, biochemical properties like $\mathrm{pH}$, titratable acidity, total soluble solids, and colour analysis were studied for fruit pulps. The viscosity of fruits was studied at various mass fractions. The high sphericity of guava and sapota indicated that those fruits had high rolling capability, which is an important factor for designing hoppers. Biochemical analysis showed that sapota was the sweetest fruit amongst the three studied.

K e y w o r d s: physical properties, guava, sapota, papaya
\end{abstract}

\section{INTRODUCTION}

This paper deals with a number of properties of the seasonal tropcal fruits guava, sapota, and papaya. Guava (Psidium guajava) fruits are generally round in shape and are hard when unripe and soft as they ripen. They range in diameter between $5-10 \mathrm{~cm}$ and exude a strong aroma when ripe. They are widely consumed fresh and processed (beverages, syrup, ice cream, and jams) (Thaipong et al., 2006). They have multitudinous stone-like seeds at the centre, which become harder as they ripen. Indian varieties have also been described by various scientists. Sapota (Manilkara zapota) is small, ranging from 5 to $9 \mathrm{~cm}$ in diameter with a round to egg-shaped appearance and weight ranging from 75 to $200 \mathrm{~g}$. The rough brown skin, which gives the fruit a somewhat unattractive appearance, encloses a soft, sweet, light brown to reddish-brown flesh. The flesh is often gritty, much like a pear, and it can hold up to 12 flat, smooth black seeds, although some fruit are seedless. Superior strains have a fine smooth texture with a slightly fragrant and sweet flavour (Mickelbart, 1996). India is the largest producer of sapota followed by Mexico, Guatemala

*Corresponding author e-mail: athmaphd@gmail.com and Venezuela. India has about 162 thousand ha of land under cultivation of sapota and produces about 1358 thousand t of sapota per year (Ministry of Commerce and Industries Data Sheet, Government of India 2009-2010) (Ajaykumar et al., 2012). Papaya (Carica papaya) plant is laticiferous as they contain specialized cells known as laticifers. Lactifiers secrete latex and are dispersed throughout most plant tissues. The papaya-latex is well known for being a rich source of the four cysteine endopeptidases namely papain, chymopapain, glycyl endopeptidase, and caricain, whose content may vary in fruit, leaves, and roots. Commercially, papaya-latex is harvested from fully-grown but unripe fruit. Papaya fruits, seeds, latex, and extracts have been used traditionally to treat various ailments in humans across the world. Papaya seed is found to be a rich source of biologically active isothiocyanate (Nakamura et al., 2007). Unripe pulp of papaya is rich in carbohydrate and starch and contains cardenolides and saponins that have medicinal value such as cardenolides used in the treatment of congestive heart failure (Schneider and Wolfing, 2004). The tropical fruits have a unique flavour and aroma, which could be exploited to make a variety of processed product from these fruits. To make various processed product and design equipment for processing, the knowledge of the physical, thermal, and rheological properties of the tropical fruits is essential.

The physical properties of tropical fruits are also important for the design of equipment for harvesting and postharvesting technology like transporting, storing, cleaning, separating, sorting, sizing, packaging, and processing it into different food. Since currently used systems have been generally designed without taking these criteria into consideration, the resulting designs lead to inadequate applications. This results in a reduction in work efficiency and an increase in product loss. Therefore, determination and consideration 
of these criteria have an important role in designing of this equipment (Haydar et al., 2007). In order to determine the dimensions of the food processing equipment, especially heat exchangers and other equipment requiring pumping of the product, it is essential to know the precise values of the thermal properties (thermal conductivity, thermal diffusivity, and heat capacity) of the products. The knowledge of physical and thermal properties of foods is essential in every stage of processing thereof into various final products. Many studies have been reported on the physical and thermal properties of fruits and vegetables such as star apple (Oyelade et al., 2005), green beans (Martins et al., 2004), apricot (Haydar et al., 2007), orange (Topuz et al., 2005) etc., but scanty literature is available on the physical, thermal, and rheological properties of guava, sapota, and papaya.

The aim of this research is to study the physical and biochemical properties of sapota, guava, and papaya that will assist in the development of appropriate machines. In order to achieve this objective, properties such as moisture content, mass, length, breadth, thickness, diameter, true density, bulk density, porosity, surface area, roundness ratio, sphericity, coefficient of friction, colour, specific heat, viscosity, and also biochemical properties like $\mathrm{pH}$, total soluble solids, and acidity were determined.

\section{MATERIALS AND METHODS}

Ripe, fresh tropical sapota, guava, and papaya fruits were used for all the experiments in this study. The fruits were cleaned to remove all foreign matter such as dust, dirt, and immature and damaged fruits. All physical properties of the tropical fruits were determined at the natural moisture contents (dry basis).

The moisture content of guava, sapota, and papaya were determined in accordance with standard procedures (AOAC, 1990). Samples of guava, sapota, and papaya (25 of each) were taken and their weights were measured on an electronic weighing machine with the $0.001 \mathrm{~kg}$ least count. The maximum, minimum, and average values of these parameters were recorded and standard deviation of the mean values was tabulated. The weight of peel, weight of seed, and weight of pulp were also computed. Linear dimensions ie length (a), width (b), and thickness (c) were measured using a digital caliper with a sensitivity of $0.001 \mathrm{~cm}$ (Ozturk et al., 2010). The criteria used to describe the shape of the fruits are the aspect ratio and sphericity. Thus, the sphericity index $\left(\mathrm{S}_{\mathrm{p}}\right)$ was accordingly computed (Mohsenin, 1970). The aspect ratio $\left(\mathrm{R}_{\mathrm{a}}\right)$ was calculated according to Maduako and Faborode (1990). The geometric mean dimension $\left(\mathrm{D}_{\mathrm{e}}\right)$ of the fruits was found using the relationship given by Mohsenin (1970). The surface area $\left(\mathrm{S}_{\mathrm{a}}\right)$ of the tropical fruits was determined using the relationship given by McCabe et al. (1986). The shell ratio $\left(\mathrm{R}_{\mathrm{S}}\right)$ was computed by dividing the shell mass $\left(M_{s}\right)$ to the fruit mass $\left(M_{f}\right)$. The packing coefficient $(\lambda)$ was determined by the ratio of the volume of fruit $(\mathrm{V})$ packed to the total volume $\left(\mathrm{V}_{0}\right)$ (Topuz et al., $2005)$. The bulk density $\left(\rho_{\mathrm{b}}\right)$ was determined with a hectoliter tester, which was calibrated in $\mathrm{kg}$ per hectoliter (Haydar et al., 2007). The tropical fruits were dropped into a cylindrical container from a height of approximately $15 \mathrm{~cm}$. The excess fruits were removed by removing the fruits from the top. The fruits were not compressed in any way. The fruit volume $(\mathrm{V})$ and true density $\left(\rho_{\mathrm{f}}\right)$ were determined using the liquid displacement method. Toluene $\left(\mathrm{C}_{7} \mathrm{H}_{8}\right)$ was used instead of water because it is absorbed by the fruit to a lesser extent. Also, its surface tension is low, so that it fills even shallow dips in a fruit and its dissolution power is low (Mohsenin, 1970; Balakrishnan et al., 2011). The porosity $(\varepsilon)$ was determined from true density and bulk density (Davies, 2010). The coefficient of static friction $\left(\mu_{\mathrm{s}}\right)$ was measured by a friction device having stainless steel, plywood, and aluminium surfaces (Baryeh, 2001). The apparent colour of the tropical fruits was measured using a Hunter colour meter. The average value of $L^{*}, a^{*}$, and $b^{*}$ was recorded by the method described by Lopez and Gómez (2004). A Brookfield Viscometer (Brookfield Engineering Laboratories: Model LVDV-II) was used to measure the rheological properties. A sample of $500 \mathrm{ml}$ of tropical fruit juice was used in a glass beaker of $600 \mathrm{ml}$ size for all experiments. The measurement range of the LVDV-II Brookfield Viscometer between 10 and 100\% full scale torque was adjusted by selection of a specific spindle (S-61; S-62; S-63; S-64) for various concentrations of fruit juices.

Specific heat capacity of fruit juice was determined by applying Newton law of cooling. The acidity was determined by the titration method, $\mathrm{pH}$ using a $\mathrm{pH}$-meter, and total soluble solids (TSS) using a refractometer (Ranganna, 2004).

\section{RESULTS AND DISCUSSION}

The summary of the results of the physical properties of guava, sapota, and papaya and standard deviation are shown in Table 1. The moisture content of guava, sapota, and papaya at the time of the experiment was $78.63,77.93$, and $90.43 \%$ w.b., respectively. The moisture content found can help to suggest the stability in storage of the fruits as well as the ease of drying and evaporation process. The average mass, length, breadth, and width of guava are $55.88 \mathrm{~g}, 0.476$, 0.471 , and $0.457 \mathrm{~cm}$, respectively. The average mass, length, breadth, and width of sapota are $48.42 \mathrm{~g}, 0.45,0.417$, and $0.457 \mathrm{~cm}$, respectively. The average mass, length, breadth, and width of papaya are $1022 \mathrm{~g}, 1.767,1.203$, and $1.243 \mathrm{~cm}$, respectively. Mohsenin (1970) had effectively highlighted the imperativeness of the axial dimensions in machine design; the comparison of the data with existing work on other fruits can be sufficient in making symmetrical projections towards process equipment adaptation. 
T a b l e 1. Physical properties of guava, sapota, and papaya

\begin{tabular}{|c|c|c|c|}
\hline Property & Guava (SD) & Sapota (SD) & Papaya (SD) \\
\hline Moisture content (\% w.b.) & $78.63(0.83)$ & $77.93(0.64)$ & $90.43(1.17)$ \\
\hline Weight (g) & $55.88(17.7)$ & $48.42(4.91)$ & $1022(162.12)$ \\
\hline Length (cm) & $4.76(0.56)$ & $4.51(0.24)$ & $17.67(1.36)$ \\
\hline Breadth $(\mathrm{cm})$ & $4.71(0.37)$ & $4.16(0.24)$ & $12.03(0.55)$ \\
\hline Width (cm) & $4.57(0.5)$ & $4.3(0.22)$ & $12.43(0.37)$ \\
\hline Weight of peel (g) & $3.28(2.45)$ & $15.32(2.34)$ & $81.1(8.39)$ \\
\hline Weight of pulp (g) & $52.6(6.74)$ & $32.26(3.45)$ & $940.7(152.78)$ \\
\hline Bulk density $\left(\mathrm{g} \mathrm{cm}^{-3}\right)$ & $0.55(0.01)$ & $0.61(0.02)$ & $0.44(0.01)$ \\
\hline True density $\left(\mathrm{g} \mathrm{cm}^{-3}\right)$ & $0.82(0.2)$ & $1.12(0.25)$ & $1.12(0.12)$ \\
\hline Porosity (\%) & $0.32(0.001)$ & $0.35(0.002)$ & $0.47(0.002)$ \\
\hline Surface area $\left(\mathrm{cm}^{2}\right)$ & $69.25(14.4)$ & $58.82(6.42)$ & $580.55(24.34)$ \\
\hline Sphericity (\%) & $98.51(3.06)$ & $95.78(0.540$ & $81.15(2.45)$ \\
\hline Aspect ratio & $99.50(5.31)$ & $92.22(1.23)$ & $71.91(2.84)$ \\
\hline Roundness index (\%) & $92.18(4.19)$ & $93.93(3.11)$ & $69.44(6.25)$ \\
\hline Shell ratio & $0.16(0.002)$ & $0.40(0.002)$ & $0.18(0.012)$ \\
\hline Packing coefficient & $0.52(0.001)$ & $0.55(0.002)$ & $0.36(0.002)$ \\
\hline \multicolumn{4}{|c|}{ Coefficient of friction } \\
\hline Stainless steel & $0.24(0.005)$ & $0.26(0.006)$ & $0.22(0.004)$ \\
\hline Plywood & $0.20(0.005$ & $0.31(0.004)$ & $0.13(0.005)$ \\
\hline Aluminium & $0.12(0.004)$ & $0.22(0.006)$ & $0.19(0.005)$ \\
\hline \multicolumn{4}{|c|}{ Colour analysis } \\
\hline$a^{*}$ & $65.70(0.11)$ & $3.61(0.15)$ & $20.77(0.13)$ \\
\hline$b^{*}$ & $39.08(0.02)$ & $17.27(0.05)$ & $20.36(0.04)$ \\
\hline$L^{*}$ & $42.37(0.09)$ & $5.17(0.01)$ & $18.04(0.02)$ \\
\hline
\end{tabular}

The sphericity of guava, sapota, and papaya is 98.52 , 95.79 , and $81.2 \%$, respectively. The aspect ratio of guava, sapota, and papaya is $99.503,92.2$, and $71.9 \%$ respectively. The sphericity and aspect ratio of guava are higher than those of sapota and papaya. The high sphericity values of guava and sapota thus suggests that the fruits tend towards a spherical shape (Omobuwajo et al., 2000). The tendency to either roll or slide should be necessary in the design of hoppers for various fruit processing equipment. The roundness index of guava, sapota, and papaya was estimated as 92.18 , 93.93, and 69.44, respectively. Comparison of the value of the roundness index allows a conclusion that guava and sapota were almost round, whereas papaya was oval-shaped.

The surface area of guava ranged from 53.53 to $100.67 \mathrm{~cm}^{2}$ with the average value being $69.25 \mathrm{~cm}^{2}$; the surface area of sapota ranged from 50.16 to $69.3 \mathrm{~cm}^{2}$ with the average value being $58.82 \mathrm{~cm}^{2}$. The surface area of papaya ranged from 516.8 to $635.7 \mathrm{~cm}^{2}$ with the average value being $580.55 \mathrm{~cm}^{2}$. Papaya fruits showed a higher surface area, whereas guava and sapota had almost the same value.
The surface area is a relevant tool in determining the shape of fruits. This will actually be an indication of the way the fruits will behave on oscillating surfaces during processing (Oyelade et al., 2005). The shell ratio of guava, sapota, and papaya is $0.163,0.401$, and 0.1828 , respectively.

The packing coefficient of the guava, sapota, and papaya is $0.52,0.55$, and 0.36 , respectively. The values of guava and sapota differ from that of papaya because of the huge difference in the volume and shape. The packing coefficient increased with the decreased fruit volume. For example, sapota had the highest packing coefficient with the lowest fruit volume.

The true density, bulk density, and porosity of guava were $824,552 \mathrm{~kg} \mathrm{~m}^{-3}$, and $33 \%$, respectively. The true density, bulk density, and porosity of sapota were $1120,610.7 \mathrm{~kg} \mathrm{~m}^{-3}$, and $36 \%$, respectively. The true density, bulk density, and porosity of papaya were $1127,449 \mathrm{~kg} \mathrm{~m}^{-3}$, and $47 \%$, respectively. These properties may be useful in separation and transportation of the fruits by hydrodynamic means. The lower porosity or percentage of the volume of voids in the 
fruits may be due to the higher sphericity and roundness, which ensure a more compact arrangement. Similar results were obtained for oranges by Topuz et al. (2005).

The static coefficient of friction of guava, sapota, and papaya against three different structural surfaces was experimented. The result indicates that the static coefficient of friction was high on the stainless steel plate $(0.24)$ for guava and papaya (0.22). Sapota fruit showed the highest static coefficient of friction on plywood (0.31). A similar result was also reported by Davies and Zibokere (2011) for gbafilo fruit and by Ahmadi (2012) for psyllium seed. These properties are the key elements for calculation of compressibility and flow behaviour of materials used for designing storage structures.

The colour analysis of the fruits was performed using Hunter colourlab; $L^{*}$ represents lightness, $a^{*}$ represents redness, and $b^{*}$ represents yellowness of the samples. The $L^{*}$ values of the samples of guava, papaya, and sapota are 65.70, 39.08 , and 42.37, respectively. Guava showed a higher $L^{*}$ value, which is more towards light colour and papaya is the least which is dark colour. The $a^{*}$ values of the guava, papaya, and sapota samples are $3.61,17.27$, and 5.17, respec- tively. Where papaya showed the highest $a^{*}$ value, which is more towards red colour and guava is the least which is of light colour. The $b^{*}$ values of the samples guava, papaya, and sapota are $20.77,20.36$, and 18.04 , respectively.

Values of the viscosity of guava, sapota, and papaya juice at different concentrations are shown in Table 2. As the content of solids increased from 10 to $100 \%$ at room temperature, the viscosity of guava increased from 0.36 to $237.8 \mathrm{~Pa} \mathrm{~s}$, that of sapota increased from 0.60 to $73 \mathrm{~Pa} \mathrm{~s}$, and that of papaya increased from 1.02 to $87 \mathrm{~Pa}$ s. The data were analysed using regression statistics with the help of Regress and MS-Excel software:

$$
\begin{gathered}
\mu_{g}=-839+55.4 \mathrm{C}\left(\mathrm{R}^{2}=0.99\right) \\
\mu_{s}=-188+8.55 \mathrm{C}\left(\mathrm{R}^{2}=0.98\right) \\
\mu_{p}=-212+10.0 \mathrm{C}\left(\mathrm{R}^{2}=0.92\right)
\end{gathered}
$$

where: $C$ is the concentration of the pulp, $\mathrm{g}$ - guava, $\mathrm{s}-$ sapota, $\mathrm{p}$ - papaya.

The viscosity of juice increased with the increase in the concentration of soluble solids and it was due to the increa-

\begin{tabular}{|c|c|c|c|c|c|}
\hline $\begin{array}{l}\text { Mass } \\
\text { fraction }\end{array}$ & $\begin{array}{c}\text { TSS } \\
\left({ }^{\circ} \text { Brix }\right)\end{array}$ & $\begin{array}{l}\text { Shear stress } \\
\left(10^{-5} \mathrm{~N}\right)\end{array}$ & $\begin{array}{c}\text { Shear rate } \\
\qquad\left(\mathrm{s}^{-1}\right)\end{array}$ & $\begin{array}{c}\text { Viscosity } \\
(\mathrm{Pa} \mathrm{s})\end{array}$ & Torque \\
\hline \multicolumn{6}{|c|}{ Guava } \\
\hline 0.1 & 2.4 & 3.65 & 1.00 & 0.36 & 11.90 \\
\hline 0.2 & 4.3 & 12.15 & 1.15 & 1.40 & 47.80 \\
\hline 0.3 & 5.3 & 163.21 & 1.02 & 16.68 & 29.00 \\
\hline 0.4 & 6.5 & 577.40 & 1.00 & 57.80 & 75.40 \\
\hline 0.5 & 7.1 & 978.32 & 1.00 & 98.00 & 54.00 \\
\hline 1 & 15.7 & 2377.14 & 1.00 & 237.80 & 36.00 \\
\hline \multicolumn{6}{|c|}{ Sapota } \\
\hline 0.1 & 4.0 & 5.99 & 1.01 & 0.60 & 20.30 \\
\hline 0.2 & 4.7 & 9.78 & 1.01 & 0.99 & 33.30 \\
\hline 0.3 & 5.6 & 27.97 & 1.01 & 2.82 & 18.90 \\
\hline 0.4 & 5.7 & 33.45 & 1.02 & 3.40 & 23.00 \\
\hline 0.5 & 6.5 & 197.65 & 1.01 & 19.90 & 33.90 \\
\hline 1 & 8.4 & 729.30 & 1.00 & 73.00 & 32.00 \\
\hline \multicolumn{6}{|c|}{ Papaya } \\
\hline 0.1 & 5.1 & 10.15 & 1.01 & 1.02 & 30.50 \\
\hline 0.2 & 6.7 & 9.57 & 1.09 & 1.04 & 34.00 \\
\hline 0.3 & 8.2 & 56.43 & 1.01 & 5.70 & 38.20 \\
\hline 0.4 & 10.3 & 94.32 & 1.02 & 9.60 & 15.70 \\
\hline 0.5 & 15.9 & 191.12 & 1.00 & 19.20 & 31.90 \\
\hline 1 & 28.8 & 869.30 & 1.00 & 87.00 & 35.40 \\
\hline
\end{tabular}
se in hydrated molecules and hydrogen bonding with the

T a b l e 2. Analysis of guava, sapota, and papaya juice properties 
T a b I e 3. Specific heat capacity of guava, sapota, and papaya at various concentrations

\begin{tabular}{cccc}
\hline \multicolumn{4}{c}{ Specific heat capacity $\left(\mathrm{kJ} \mathrm{kg}^{-1} \mathrm{~K}\right)$} \\
\hline Mass fraction & Guava & Sapota & Papaya \\
\hline 0.1 & 3.95 & 4.11 & 4.08 \\
0.2 & 3.73 & 4.11 & 4.02 \\
0.3 & 3.67 & 4.01 & 3.98 \\
0.4 & 3.62 & 3.81 & 3.59 \\
0.5 & 3.94 & 3.88 & 3.59 \\
1 & 3.47 & 3.94 & 3.51 \\
\hline
\end{tabular}

T a b l e 4. Biochemical analysis of guava, sapota, and papaya

\begin{tabular}{cccc}
\hline Samples & $\mathrm{pH}$ & $\begin{array}{c}\text { Titratable } \\
\text { acidity }(\%)\end{array}$ & $\begin{array}{c}\text { TSS } \\
\left({ }^{\circ} \text { Brix }\right)\end{array}$ \\
\hline Guava & 4.8 & 1.3 & 9.7 \\
Sapota & 5.2 & 1.8 & 11.8 \\
Papaya & 5.5 & 1.2 & 8.2 \\
\hline
\end{tabular}

hydroxyl groups of solutes. The sugar content plays an important role in the magnitude of the viscosity of juices, a similar result was also reported by Manjuanatha et al. (2012) in Indian gooseberry juice and by Nindo (2005) in red raspberry juice and blueberry juice. According to Renata et al. (2009), viscosity is a function of intermolecular forces and water-solute interactions that restrict the molecular motion. These forces depend upon intermolecular spacing and the strength of the hydrogen bonds, and are affected by changes in both concentration and temperature.

Specific heat capacity is defined as the quantity of heat gained or lost by a unit mass of fruits and their juices to accomplish a unit change in temperature. The specific heat of guava, sapota, and papaya were $3.47,3.94$ and $3.51 \mathrm{~kJ} \mathrm{~kg}^{-1} \mathrm{~K}$, respectively. From these values, it was observed that the specific heat values for the fruits were as high as thousands of joules per kilogram for a unit change in temperature. This translates that lot of energy will be need to heat or cool these fruits. This is a result of large moisture contents of these fruits. Lamb (1976) reported that water retains its temperature for a long time due to its high specific heat capacity value. Beside water, specific heat capacity is also influenced by protein and fat (Wang and Brennan, 1993). Additionally, specific heat capacity was determined for guava, sapota, and papaya fruit pulp at various mass fractions (Table 3 ). It was noticed that the lesser the mass fraction of the sample, the greater the specific heat capacity was. This is indicative of the fact that the higher the moisture content of the sample, the greater the time taken by it to cool down is. This result was similar to the work done by Wang and Brennan (1993) for potato and Zainal et al. (2001) for pink guava juice. Muramatsu et al. (2000) noticed the temperature dependence of specific heat capacity and reported that the higher the temperature, the higher the specific heat capacity.

The biochemical properties like $\mathrm{pH}$, titrate acidity, and total soluble solids (TSS) of guava, sapota, and papaya are shown in Table 4. Acids and sugars are important components, which provide characteristic taste and flavour to fruits and their products. The quality of the fruit juice is often expressed in terms of the sweetness-to-sourness ratio ( ${ }^{\circ}$ Brix/acid). Guava fruit has a characteristic flavour due to its acidity (Jagtiani et al., 1988). Flavour quality of the commodity which determines fruit value to consumers depends on the content of sugars, organic acids, etc. (Sonu and Ramana, 2013). The $\mathrm{pH}$ of guava, sapota, and papaya was $4.8,5.2$, and 5.5, respectively. The lower $\mathrm{pH}$ value of guava indicates that it tastes sour, compared with sapota and papaya. Titratable acidity (\%) of guava, sapota, and papaya was 1.3 , 1.8 , and 1.2 , respectively. Papaya is highly perishable due to its low acid value. The TSS of guava, sapota, and papaya was $9.7,11.8$, and 8.2. The high TSS rendered the sapota as one of the sweetest fruits.

\section{CONCLUSIONS}

1. The sphericity of guava, sapota, and papaya was 98.52 $\pm 3.1 \%, 95.79 \pm 0.54 \%$, and $81.2 \pm 2.5 \%$, respectively. The aspect ratio of guava, sapota, and papaya is $99.503 \pm 5.32 \%$, $92.2 \pm 1.2 \%$, and $71.9 \pm 2.8 \%$, respectively. The high sphericity of guava and sapota indicated that those fruits had high rolling capability, which is an important factor for designing hoppers.

2. As the content of solids increased from 10 to $100 \%$ at room temperature, the viscosity of guava increased from 0.36 to $237.8 \mathrm{~Pa} \mathrm{~s}$, that of sapota increased from 0.60 to $73 \mathrm{~Pa} \mathrm{~s}$, and that of papaya increased from 1.02 to $87 \mathrm{~Pa} \mathrm{~s}$.

3. Colour analysis showed that guava pulp had the lightest colour, while sapota was the darkest, and the colour of papaya was more inclined towards reddish. Biochemical analysis showed that sapota was the sweetest fruit amongst the three studied.

\section{REFERENCES}

Ahmadi R., Kalbasi A., and Gharibzahedi S.M.T., 2012. Physical properties of psyllium seed. Int. Agrophys., 26, 91-93.

Ajaykumar M., Madhukar G.B., and Pratima N.S., 2012. Studies on preparation of fortified sapota-papaya fruit bar. Nutrition Food Sci., 25, 41-44.

AOAC, 1990. Moisture in dried fruits. In: Official methods of analysis. Association of Official Analytical Chemists, Washington, USA.

Balakrishnan M., Manikantan M.R., Viswanathan R., and Sreenarayanan V.V., 2011. Moisture dependent physical properties of cardamom. Int. Agrophys., 25, 399-402.

Baryeh E.A., 2001. Physical properties of bambara groundnuts. J. Food Eng., 47(4), 321-326. 
Davies R.M., 2010. Some physical properties of arigo seeds. Int. Agrophys., 24, 89-92.

Davies R.M. and Zibokere D.S., 2011. Some physical properties of gbafilo (Chrysobalanus icaco) fruits and kernels preparatory to primary processing. Int. J. Agric. Res., 6(12), 848-855.

Haydar H., Ibrahim G., Mehmet M., and Bayram M., 2007. Post harvest chemical and physical-mechanical properties of some apricot varieties cultivated in Turkey. J. Food Eng., 49, 303-310.

Indian Horticulture Database, 2011. Ministry of Agriculture. Government of India, New Delhi, India.

Jagtiani J., Chang H.T., and Sakai W.S., 1988. Guava. Tropical Fruit Processing, Academic Press, New York, USA.

Lamb J., 1967. Experimental study. Influence of water on the physical properties of foods. Chem. Industry, 24, 1046-1050.

Lopez C.A.F. and Gómez P.A., 2004. Comparison of color indexes for tomato ripening. Hort. Brasileira, 22(3), 534-537.

Maduako J.N. and Faborode M.O., 1990. Some physical properties of cocoa pods in relation to primary processing. IFE J. Technol., 2, 1-7.

Manjuanatha S.S., Raju P.S., and Bawa A.S., 2012. Rheological behaviour of enzyme clarified Indian gooseberry juice. Int. Agrophys., 26, 145-151.

Martins R.C. and Silva C.L.M., 2004. Frozen green beans (Phaseolus vulgaris L.) quality profile evaluation during home storage. J. Food Eng., 64(4), 481-488.

McCabe W.L., Smith J.C., and Harriot P., 1986. Unit Operation of Chemical Engineering. McGraw Hill Press, New York, USA.

Mickelbart M.V., 1996. Sapodilla: A potential crop for subtropical climates. In: Progress in New Crops (Ed. J. Janick). ASHS Press, Alexandria, VA, USA.

Mohsenin N.N., 1970. Physical properties of plant and animal materials. Gordon and Breach Press, New York, USA.

Muramatsu Y., Tagawa A., Kasai T., Sakai H., and Fukushima M., 2000. Thermophysical properties of apple juice. J. Japanese Soc. Food Sci. Technol., 47, 548-550.

Nakamura Y., Yoshimoto M., Murata Y., Shimoishi Y., Asai Y., and Park E.Y., 2007. Papaya seed represents a rich source of biologically active isothiocyanate. J. Agric. Food Chem., 55(11), 4407-4413.

Nindo C.I., Tang, J., Powers J.R., and Singh P., 2005. Viscosity of blueberry and raspberry juices for processing applications. J. Food Eng., 69(3), 343-350.

Omobuwajo T.O., Sanni L.A., and Olajide J.O., 2000. Physical properties of ackee apple seeds. J. Food Eng., 45(1), 43-48.

Oyelade O.J., Odugbenro P.O., Abioye A.O., and Raji N.L., 2005. Some physical properties of African star apple (Chrysophyllum alibidum) seeds. J. Food Eng., 67(4), 435-440.

Ozturk I., Bastaban S., Ercisli S., and Kalkan F., 2010. Physical and chemical properties of three late ripening apple cultivars. Int. Agrophys., 24, 357-361.

Ranganna S., 2004. Handbook of Analysis and Quality. Control for Fruit and Vegetable Products. Tata Mc. Graw Hill Press, New Delhi, India.

Renata C.F.B., Rafael C.I.F., Tatiana S.S., Cristiane M.V., Maycon F.T.R., and Sérgio S.C., 2009. Thermophysical properties of cashew juice at different concentrations and temperatures. Revista Brasileira de Produtos Agroindustriais, Campina Grande, 11, 35-42.

Schneider G. and Wolfing J., 2004. Synthetic cardenolides and related compounds. Current Organic Chemistry, 8, 13811403.

Sonu S. and Ramana Rao T.V., 2013. Nutritional quality characteriscits of pumpkin fruit as revealed by its biochemical analysis. Int. Food Res. J., 20(5), 2309-2316.

Thaipong K., Boonprakob U., Crosby K., Cisneros-Zevallos L., and Hawkins Byrne D., 2006. Comparison of ABTS, DPPH, FRAP, and ORAC assays for estimating antioxidant activity from guava fruit extracts. J. Food Composition Analysis, 19(6), 669-675.

Topuz A., Topakci M., Canakci M., Akinci I., and Ozdemir F., 2005. Physical and nutritional properties of four orange varieties. J. Food Eng., 66(4), 519-523.

Wang N. and Brennan J.G., 1993. The influence of moisture content and temperature on the specific heat of potato measured by differential scanning calorimetry. J. Food Eng., 19(3), 303-310.

Zainal B.S., Rahman R.A., Ariff A.B., Saari B.N., and Asbi B.A., 2001. Thermophysical properties of pink guava juice at 9 and 11 Brix. J. Food Process Eng., 24(2), 87-100. 